\title{
Conservation of Great Bustard (Otis tarda) population of the Mosoni-Plain - A success story
}

\author{
SÁNDOr Faragó ${ }^{1 *}$, Péter Spakovszky ${ }^{2} \&$ RaIner RaAB ${ }^{3}$
}

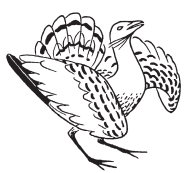

Sándor Faragó, Péter Spakovszky \& Rainer Raab 2014. Conservation of Great Bustard (Otis tarda) population of the Mosoni-Plain - A success storyt. - Ornis Hungarica 22(2): 14-31. mained in the Hungarian and Austrian territories. Of the many possible negative factors of current times, the greatest pressure on the Great Bustard population stems from unfavorable crop structures, extensive use of intensive agricultural technologies and predation. During the past decades, we have seen a shift in nesting place locations from natural-like habitats to agrar-type habitats. This change may be explained by the more favorable structure and microclimate of this latter habitat type paralleled with greater food source availability. In order to escape this ecological trap, we have to engage in active conflict resolution that provides protection for the region's Bustard population.

For this very reason, the MOSON Project was founded in 1992 at the northern part of the Mosoni-Plain in the territory of Lajta-Hanság Co. Later, several Austrian regions joined the project. On these territories, out of the above mentioned 100 specimens, only 20 birds lived at the time. As the result of active habitat management of Great Bustards and coexisting small game species (mostly due to the influence of set-aside areas) as well as effective predator control (especially the Red Fox) resulted in an increase of the Great Bustard population. By the end of the 1990's, the population grew to 120-130 individuals which number was limited by the carrying capacity of this territory. Consequently, the species continued to reoccupy new regions in the Hungarian and Austrian territories. These days, the number of Great Bustards in these protected regions is estimated to be 400 individuals.

In 1998, the Mosoni-plain was given IBA (HU-001) status, and in 2004, the region was protected under the NATURA 2000 EU nature conservation network.

Keywords: Otis tarda, MOSON Project, habitat improvement, predator control, agri-environmental scheme

Összefoglalás A 19-20. század fordulóján a Kisalföld túzokállománya még mintegy 4000 példány volt. 1990-re ebből a létszámból már csak mintegy 100 példány maradt fenn Magyarország és Ausztria területén. A sok negatív tényező közül napjainkban a kedvezőtlen vetésszerkezet, az intenzív termesztéstechnológiák és a predáció fejti ki a legnagyobb nyomást a túzokpopulációra. Az elmúlt évtizedekben a faj fészkelőhely váltását figyelhettük meg a természetszerủ élőhelyek rovására, egyszersmind a szántóföldi habitatok javára. A váltás utóbbi élőhelyek kedvezőbb struktúrájával, mikroklímájával, valamint jobb növényi és állati eredetű táplálék kínálatával magyarázható. Ebből az ökológiai csapdából csak aktív, a konfliktusokat feloldó túzokvédelmi tevékenységgel tudunk kikerülni.

E célt szolgálja a Mosoni-sík északi részén, a Lajta-Hanság Zrt. területén 1992-ben alapított MOSON Project, melyhez csatlakoztak a későbbiekben osztrák területek is. E területen az említett 100 példányból 20 madár élt. A túzok és a koegzisztens apróvad fajok érdekében végzett aktív élőhelygazdálkodás (mindenekelött a set-aside területek dominanciája), valamint predátor (főként róka) kontrol azt eredményezte, hogy a túzokpopuláció az 1990-es évek végére elérte a 120-130 példányt, ami a terület eltartó képességének tekinthető. Ezt követően a faj mind magyar, mind osztrák területen újabb területeket foglalt vissza, s mára a térség túzokállományát mintegy 400 példányra becsüljük.

A Mosoni-sík 1998-ban IBA (HU-001), 2004-ben pedig NatURA 2000 terület lett. 
${ }^{1}$ University of West-Hungary, Institute of Wildlife Management and Vertebrate Zoology, Faculty of Forestry, 9400 Sopron, Bajcsy-Zsilinszky u. 4., Hungary, e-mail: farago@emk.nyme.hu

${ }^{2}$ Technisches Buro fur Biologie, Quadenstr. 13, A-2232 Deutsch-Wagram, Osterreich, e-mail: spakovszky@ yahoo.com

${ }^{3}$ Technisches Buro fur Biologie, Quadenstr. 13, A-2232 Deutsch-Wagram, Osterreich, e-mail: rainer.raab@ gmx.at

*corresponding author: farago@emk.nyme.hu

\section{Introduction}

At the turn of the $19^{\text {th }} / 20^{\text {th }}$ century, the Great Bustard population of the Kisalföld spread across significantly larger territories than today and numbered approximately 800-900 individuals. There was also a large population of the species present in Austria with approximately 1000 birds, and in regions of the present-day Slovakia with about 2000 individuals. These population numbers were fairly constant up until the winter of 1928/1929. In the 1941 national survey, as direct consequence of the aforementioned year's winter conditions, only 500 bustards were counted in the Kisalföld region. After the war, in the 1950's, estimated size of the population was around 300 individuals; but by 1969 when the Great Bustard was given protection status, the population reduced to only 137 birds (Faragó 1978, 1993). Even though there is statistical data available from the hunting seasons of 1969-2003, due to the unsynchronized nature of the applied counting methods, in many cases, reported results differed significantly from the actual population size of the time. During 1973 and 1976, the population consisted of only 94-101 individuals. Five years later, in 1981, this continuous decline in population size was already apparent as we counted only 80-87 individuals. By 1989, the nesting population was made up of only 55-61 birds. During this period, almost the entire SouthHanság subpopulations disappeared, paralleled with notable declines in the Jánosso- morja (Tóbi-liget) and Császárrét regions (Faragó 1982, 1986a, 1988, 1993, 1996a, Faragó et al. 1987).

In an attempt to identify the causes of this dramatic decline in population size (Faragó 2006), we determined nine key factors which have negatively influenced population dynamics: (1) harsh winters, (2) floods, drainage waters and extreme precipitation during breeding season, (3) fire damages, ground fires, (4) decline of suitable habitat for the Great Bustard due to changes in habitat structures, (5) effects of land ownership changes, (6) changes in crop structure on agricultural lands, (7) intensive crop production technologies (8) predation and (9) hunting pressure. Of these factors, there are several which no longer have an effect on the current population $(2,3,4,5,9)$, while others rarely have an impact ( 1 and in part 2 ). Of the remaining negative factors of current times, the greatest pressure on the Great Bustard population stems from unfavourable crop structures, extensive use of intensive agricultural technologies and predation. These negative factors are even more intensified by the fact that the bustard is relatively conservative in its choice of lek territory as the birds show strong preference for specific sites. This behaviour can also be seen in the Kisalföld population (Faragó 1978, 1990). In addition, there is also a strong pattern for nesting site changes where the birds preferentially relocate to cropped agricultural sites from naturally occurring habitats. This change may be explained by the 
more favourable structure and microclimate of agricultural habitats paralleled with greater food source availability (Faragó 1979, 1981, 1986b). In order to escape this ecological trap, we have to engage in active conflict resolution which addresses the above issues and which provides protection for the region's Great Bustard population (Faragó 1989, 1996b).

Taking into consideration all these aspects, in 1992, we have established the MOSON Project in the Northern part of the Mosoni-plain in the Rajka/Hegyeshalom region, which encompassed 1232 hectares. The Great Bustard conservation program on the Lajta-Hanság Co. territory was initiated by the University of Sopron, Department of Game Management (today the University of West-Hungary, Institute of Wildlife Management and Vertebrate Zoology) in partnership with the Lajta-Hanság Co., the Fertö-Hanság National Park and WWF Austria. The aim of the conservation program was to increase the size of the population, which numbered only 20 individuals at the time, by means of facilitating ecologically supportive technologies (Faragó et al. 2001, Spakovszky et al. 2011).

\section{Material and Methods}

Before 1992 prior to initiation of the MOSON Project, the area of the Lajta-Hanság Co. was utilized for agricultural activity with all of the negative impacts of large scale habitat structures and applied growing technologies. Until 1991, most of the area was used for grain and rape (sometimes maize) production, further 169 hectares of land was utilized for sheep pasture and 20 hectares was left for meadows. When the Project began, grasslands and pastures were left uncut and the previously uncultivated agricul- tural lands were unutilized. Size of this area was 543 hectares which was a total of $44 \%$ of the Project's entire territory. As a result of extreme drought in 1991, the rape plantation yield was so low that harvesting costs would have outweighed any expected profits; therefore, that year's harvest was forgone. As a result of this, we have gained another 351 hectares of untouched land which expanded the protected 'bustard-friendly' region to 894 hectares $(73 \%)$. The Project Directives - as entered into contract - were the following:

\section{Agricultural activity}

- Sheep pastures may only be utilized earliest from the middle of June but preferentially from the end of July

- Meadows may not be utilized for hay harvesting; cutting of meadows has to be done in September and/or October of every second year. This can also be achieved by means of grazing in September or October of these given years

- From 1994 onwards, winter barley should be changed to winter wheat which requires 3-4 weeks of delayed harvest

- Rye may not be treated with pesticides at all, whereas winter barley and winter wheat may only be treated up until the $15^{\text {th }}$ of April

- Up until the date of harvest, no agricultural activity of any kind may be performed in the area

- Rape fields may only be treated against pests up until April $30^{\text {th }}$ the latest

- In the event that some unexpected condition arises, which may have a negative impact (for example drought), harvesting of rape must forgo. In such years, the WWF Austria may offer monetary compensation for loss of harvest in certain 
rape-planted agricultural areas to ensure protection of nesting birds.

- Feeding of green-stage plants and topdressing-type fertilization of vegetation during the growing season are prohibited in case of all four crops.

\section{Hunting / game management}

- The LAJTA-HANSÁG Co. Hunting and Tourism Operation and their Austrian partner JAGDVERWALTUNG FLICK have agreed upon parallel time hunting utilization of the territory. The agreement ensures that during breeding season and in the nesting period, the birds remain undisturbed, as well as the agreement guarantees equal hunting opportunities for both parties.

- In case of Roe Deer (Capreolus capreolus) hunting, the parties have agreed to a hunting period different from the otherwise accepted hunting seasons in Hungary or in Austria. According to this: hunting period for Roe bucks is set between July $20^{\text {th }}$ to September $30^{\text {th }}$,

- and hunting for does and fawns is only permitted between October $1^{\text {st }}$ and February $15^{\text {th }}$.

- Within this time frame, both countries shall follow their own hunting season guidelines. The permitted hunting season date may be adjusted depending on any changes to the hunting guidelines of each country.

- During hunting (of Roe Deer), use of cars is strictly restricted to road ways in order to minimize any disturbance of Great Bustards who are guiding their chick.

Predator control is an ultimate necessity of any effective conservation program that aims to protect Great Bustards, birds in general or any other types of game. In light of this, in the 1990 's, we annually placed 500 pieces of F2-treated eggs (with 3-chloro-4-methylaniline hydrochloride active substance specifically selected for crows) to limit the local crow population (of course this population was also under armed control). As a result, there were no Magpies (Pica pica) or Hooded Crows (Corvus corone cornix) nesting in the conservation territory. Population control of the Red Fox (Vulpes vulpes) was intensively performed by means of gun control, trapping and den hunting, especially since the vaccination (immunization) program against rabies - which began in 1993 - included the Project's territory as well.

Based on the above parameters, records were kept continuously and summarized annually. These included data on changes in habitat structures including developments, recording and mapping of habitats, agricultural land use and activity.

Continuous survey of the Project's region enabled us - based on complete population assessment - to estimate the size of the local Great Bustard population especially during the mating and autumn seasons. We also recorded sex ratios and successfully reared offspring output for the population. During the mating season and in winter, by synchronous counting, we were able to survey the West-Pannonian Great Bustard population as well (Raab et al. 2010).

Due to the nature of wildlife in the region, we also recorded the size and dynamics of hunting bags for Brown Hare (Lepus europaeus) and Roe Deer for each year.

We determined changes in predation pressure based on Red Fox hunting bag size.

Student t-test was used to compare the number of Red Foxes before and after 2000. We used linear regression to estimate trends in the number of individuals (Reiczigel et al. 2007). 


\section{Results}

\section{Habitat development}

In the autumn of 1992, we established a socalled 'bustard-field' area which spanned over 25 hectares. On this land we planted a seed mixture of rape $(5 \mathrm{~kg} / \mathrm{ha})$, alfal$\mathrm{fa}(20 \mathrm{~kg} / \mathrm{ha})$ and winter barley $(100 \mathrm{~kg} / \mathrm{ha})$. Unfortunately, severe drought in that season hindered seed germination; therefore, the crop mixture was only able to provide food source in the seedling stage. Later, the seedlings got frost bitten and perished in the winter cold. However, even in such conditions, weeds germinated along with the crop mix offered large sources of green plant food in the spring time. In 1993, that multilateral agreement came into effect which specified the following habitat structure for the Project: Meadow: 20 ha, fallow: 746 ha, Bustard-field strips: 25 ha, Rape: 95 ha, Winter Barley: 72 ha and Rye: 105 ha (Total 1232 ha).

Agricultural activity was limited to only $22.1 \%$ of the territory, whereas 'bustard-friendly' territories extended to $77.9 \%$ (960 hectares). Due to the effect of extreme drought, the rape fields remained unharvested; therefore, we gained another 95 hectares of undisturbed territory. The only crops harvested in that year were barley (72 ha of land) and rye (105 ha of land). In the fall, withered tall weed-type vegetation was partly ploughed, while remaining weedy vegetation was flattened by heavy smoothing-plane before hunts in the area. In 1993/1994, 25 hectares of 'bustard-field' was planted with $100 \%$ rape. The plantation was fairly successful; therefore, it provided adequate food source for the winter. In addition to making the habitat structure of the territory more 'bustard-friendly', we also tried, as much as possible, to make the crops and associated agricultural practices less destructive to the population.

From 1994 onwards, we diversified the vegetation cover of the MOSON Project's territory by breaking up the monotony of the grass and uncultivated agricultural land areas and planted strips of rape, rye and spring barley. Location of these strips changed every year and as a result, these areas became 1-23-4 etc. year old fallows that each supported different flora and Arthropod fauna. In order to maintain desirable vegetation structures of uncultivated agricultural lands, it was unavoidable that we do some form of management; therefore, at the end of September/ beginning of October, the tall vegetation of these areas (mostly $1^{\text {st }}$ and $2^{\text {nd }}$ year fallows) were shredded. Every year, these associated costs were funded by the WWF Austria. This type of habitat management and the resulting habitat characteristics of the region continued until 2003. In 1995, as a result of state compensations (restitutions), four parcels of land from the Northeast region of the Project, as well as portion of the parcel located beside the left bank of the Lajta river canal, got out of the Lajta-Hanság Co.'s management; therefore, the Project's habitat-managed region decreased by 842 hectares.

Between 2004-2009, the Lajta-Hanság Co. won support of the so called 'Agricultural crop production based on bustard habitat development guidelines' agri-environment scheme management program, which yielded 5042 hectares of protected land of which the MOSON Project was also a part of. As part of the implementation program in the Project's region, which now was concentrated to 872 hectares, we continued with the already utilized strip type habitat management technique and established various grains (winter wheat, winter bar- 


\begin{tabular}{|l|c|c|c|c|}
\hline \multicolumn{1}{|c|}{ Habitat (\%) } & $\mathbf{2 0 0 5 / 2 0 0 6}$ & $\mathbf{2 0 0 6 / 2 0 0 7}$ & $\mathbf{2 0 0 7 / 2 0 0 8}$ & $\mathbf{2 0 0 8 / 2 0 0 9}$ \\
\hline Winter wheat & 3.5 & 0.0 & 0.0 & 0.0 \\
\hline Winter crops (mixed) & 0.0 & 0.0 & 0.0 & 6.5 \\
\hline Triticale & 0.0 & 7.7 & 8.4 & 0.0 \\
\hline Crimson clover & 0.0 & 0.5 & 0.0 & 0.0 \\
\hline Pea & 8.4 & 0.0 & 0.0 & 0.0 \\
\hline Rape & 0.0 & 1.4 & 3.5 & 2.6 \\
\hline Fallow & 0.0 & 0.5 & 0.0 & 0.0 \\
\hline Total cultivated land & 11.9 & 10.1 & 11.9 & 9.1 \\
\hline Total uncultivated agricultural & 88.1 & 89.9 & 88.1 & 90.9 \\
\hline land-fallow & 100 & 100 & 100 & 100 \\
\hline Total MOSON Project & & & & \\
\hline
\end{tabular}

Table 1. Changes of the habitat structure between 2005-2009 in the MOSON Project 1. táblázat Az élőhely-szerkezet alakulása 2005-2009 között a MOSON Projectben

ley, triticale) and cow-grass, peas and rape in alternating plantation strips. $9.1-11.9 \%$ of the territory became cultivated agricultural land, whereas $88.1-90.9 \%$ was left as fallow area (Table 1).

In 2009, the land owner was awarded funding by the AKG (agri-environment scheme management program) for another 5 year period. However, the 'migrating' bustard-land management technique could no longer be followed by the land registry. Therefore, we converted to a management technique which enabled us to perform fallow land management for a maximum of 3 years after a 1 year of active cultivation period of the land. The proportion of alfal- fa in the Project was 7.5\% (64.7 ha) which was distributed in 13 land strips. In addition, in one of the years, partly due to crop rotation and limitations of the agricultural region, we also planted rape (97.3 ha $11.3 \%$ ). From grains, due to local technological limitations, we chose winter barley to be grown in the area (35.1-262.0 ha-4.1$30.4 \%)$. However, most of the territory remained as fallow lands (502.4-796.8 ha 58.3-92.5\%) (Table 2, Map 1).

\section{Predator control}

The Lajta-Hanság Co., as we have already discussed, continues to engage in intensive

\begin{tabular}{|l|c|c|c|c|c|}
\hline \multicolumn{1}{|c|}{ Habitat (\%) } & $\mathbf{2 0 0 9 / 2 0 1 0}$ & $\mathbf{2 0 1 0 / 2 0 1 1}$ & $\mathbf{2 0 1 1 / 2 0 1 2}$ & $\mathbf{2 0 1 2 / 2 0 1 3}$ & $\mathbf{2 0 1 3 / 2 0 1 4}$ \\
\hline Fallow & 92.5 & 58.3 & 64.6 & 62.1 & 88.4 \\
\hline Alfalfa & 7.5 & 7.5 & 7.5 & 7.5 & 7.5 \\
\hline Winter barley & 0.0 & 22.9 & 27.9 & 30.4 & 4.1 \\
\hline Rape & 0.0 & 11.3 & 0.0 & 0.0 & 0.0 \\
\hline Total MOSON Project & 100 & 100 & 100 & 100 & 100 \\
\hline
\end{tabular}

Table 2. Changes of the habitat structure between 2009-2014 in the MOSON Project 2. táblázat Az élőhely-szerkezet alakulása 2009-2014 között a MOSON Projectben 


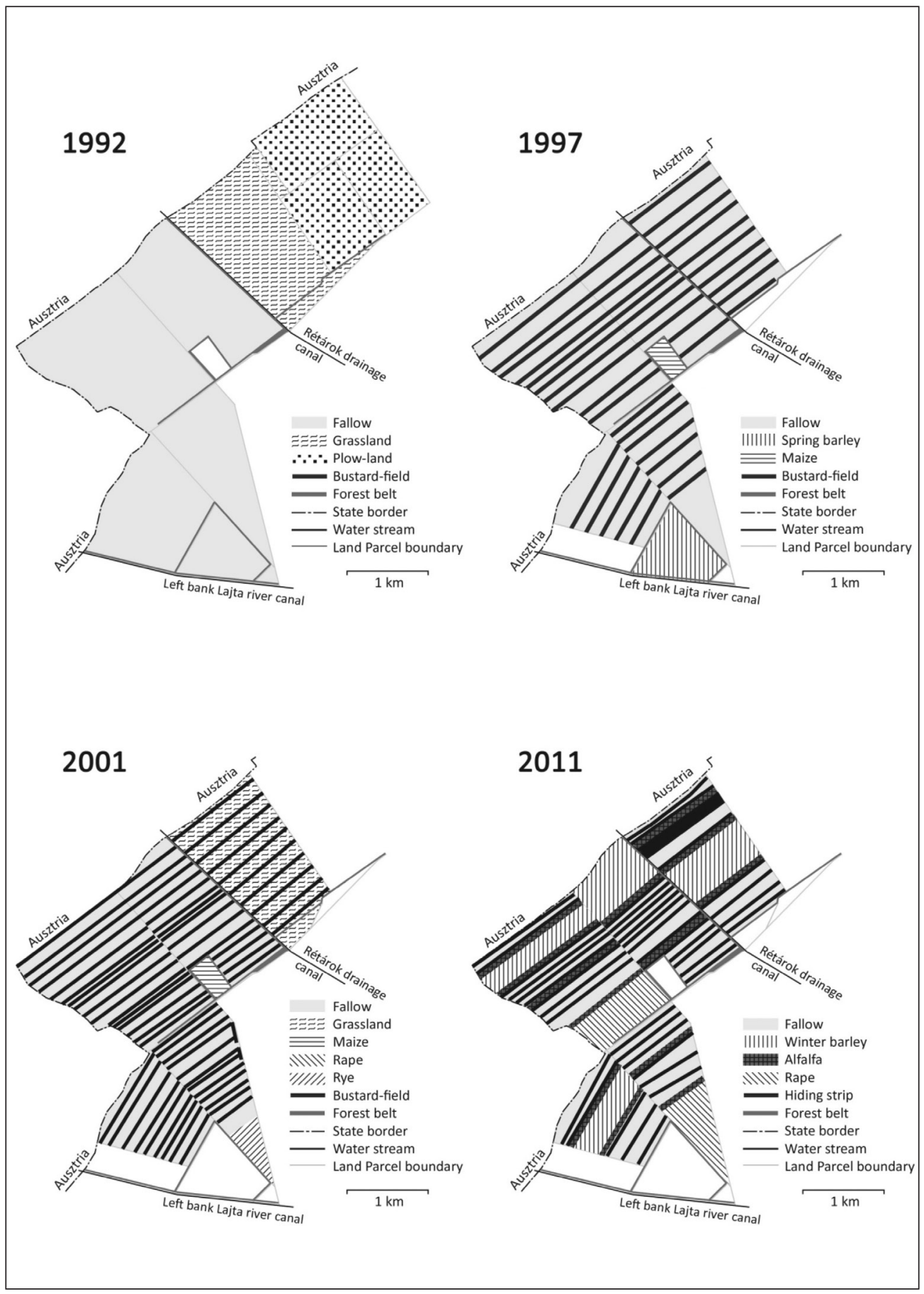

Map 1. Habitat development in the MOSON Project

1. térkép Élőhelyfejlesztések a MOSON Project-ben 


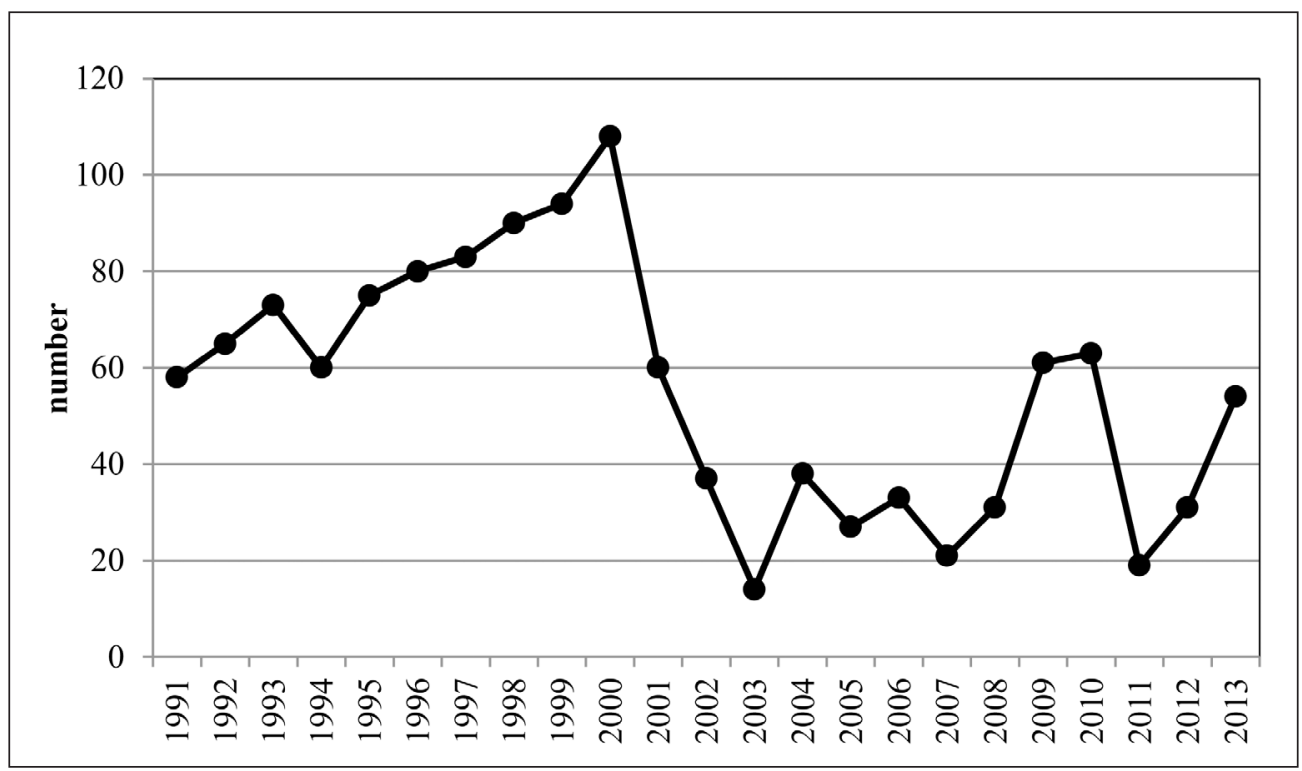

Figure 1. Red Fox hunting bag dynamics between 1990-2013 in the MOSON Project 1. ábra A vörös róka terítékdinamikája 1990-2013 között a MOSON Projectben

predator control in the region since the beginning of the Project. In case of the Corvidae (which have not nesting colony present locally), the control focuses on settlement avoidance from the adjacent Szigetköz area or Austrian territories. For Magpies, this type of management is highly effective. However, in case of the Hooded Crow, the incoming transient population from the Szigetköz and Austria is significant enough for these birds to continue to be present in the Project's territory. The most intensive work concentrated on predator control of the Red Fox population (Figure 1). Foxes decreased by 41 (CI: 26.7; 55.2, $\mathrm{P}<0.0001)$ after 2000.

\section{Great Bustard population dynamics}

Based on the sprig population assessment of the MOSON Project, the initial Great Bustard population of the region was 20 individuals (Figure 2). As of 1992, this population size began to grow as a direct result of the implemented habitat management measures. These changes had a positive impact on offspring survival to adulthood, which up until that point most often perished due to the destructive nature of the past agricultural activities of the region. Significant recovery was finally seen from 1995 when the successfully reared female chicks born in 1992 reached sexual maturity. They then increased the reproductively active population of hens who laid eggs and successfully reared their own chicks. From 1998, a significant population boom was expected which was reflected in the spring and autumn population surveys where the number of Great Bustards reached or exceeded 120 individuals. Assuming a linear trend, the yearly rate of growth is $5.7(\mathrm{SE}=0.73, \mathrm{P}<0.0001)$ individuals in case of spring during the whole time period, and $14.1(\mathrm{SE}=3.5, \mathrm{P}=0.0007)$ individuals until 1999 in case of autumn. After 1999 no trend can be seen in the number of Great Bustards in autumn. We specu- 


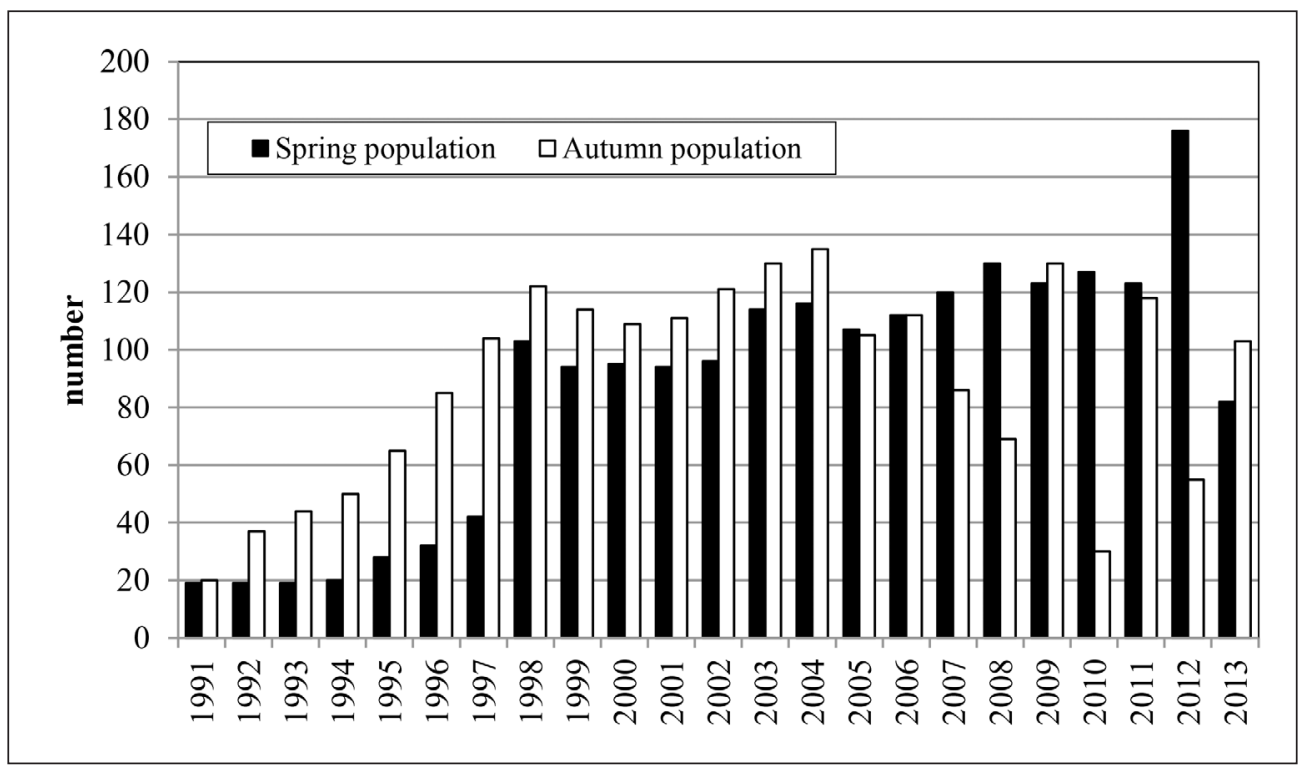

Figure 2. Great Bustard population dynamics between 1991-2013 in the MOSON Project 2. ábra A túzokállomány dinamikája 1991-2013 között a MOSON Projectben

\begin{tabular}{|l|r|r|r|r|r|r|r|r|r|r|}
\hline & 1991 & 1992 & 1993 & 1994 & 1995 & 1996 & 1997 & 1998 & 1999 & 2000 \\
\hline Cock & 6 & 6 & 6 & 6 & 6 & 10 & 14 & 41 & 24 & 22 \\
\hline Hen & 13 & 13 & 13 & 14 & 22 & 22 & 28 & 62 & 70 & 73 \\
\hline Spring population & 19 & 19 & 19 & 20 & 28 & 32 & 42 & 103 & 94 & 95 \\
\hline Chick & 1 & 17 & 9 & 13 & 15 & 26 & 19 & 19 & 20 & 14 \\
\hline Fall population & 20 & 37 & 44 & 50 & 65 & 85 & 104 & 122 & 114 & 109 \\
\hline & 2001 & 2002 & 2003 & 2004 & $\mathbf{2 0 0 5}$ & $\mathbf{2 0 0 6}$ & $\mathbf{2 0 0 7}$ & $\mathbf{2 0 0 8}$ & $\mathbf{2 0 0 9}$ & $\mathbf{2 0 1 0}$ \\
\hline Cock & 22 & 21 & 26 & 29 & 45 & 52 & 54 & 56 & 49 & 45 \\
\hline Hen & 72 & 68 & 88 & 87 & 62 & 60 & 66 & 74 & 74 & 82 \\
\hline Spring population & 94 & 96 & 114 & 116 & 107 & 112 & 120 & 130 & 123 & 127 \\
\hline Chick & 17 & 18 & 16 & 19 & 11 & 5 & 7 & 8 & 6 & 2 \\
\hline Fall population & 111 & 121 & 130 & 135 & 105 & 112 & 86 & 69 & 130 & 30 \\
\hline
\end{tabular}

\begin{tabular}{|l|r|r|r|}
\hline & $\mathbf{2 0 1 1}$ & $\mathbf{2 0 1 2}$ & $\mathbf{2 0 1 3}$ \\
\hline Cock & 40 & 57 & 48 \\
\hline Hen & 83 & 119 & 34 \\
\hline Spring population & 123 & 176 & 82 \\
\hline Chick & 8 & 4 & 7 \\
\hline Fall population & 118 & 55 & 103 \\
\hline
\end{tabular}

Table 3. Estimated size of the Great Bustard population between 1991-2013 in the MOSON

3. táblázat A túzokállomány becsült létszáma 19912013 között a MOSON Projectben 


\begin{tabular}{|c|c|c|c|c|c|}
\hline Year & Heideboden (A) & $\begin{array}{c}\text { Parndorfer } \\
\text { Platte (A) }\end{array}$ & Hanság (A) & Kisalföld (H) & Total \\
\hline 1990 & 0 & 6 & 16 & 86 & 108 \\
\hline 1996 & 1 & 6 & $14-16$ & $65-66$ & $86-89$ \\
\hline 2000 & 14 & 8 & $10-14$ & 89 & $121-125$ \\
\hline 2003 & $34-67$ & $9-10$ & $16-17$ & 114 & $173-208$ \\
\hline 2005 & $60-82$ & 8 & $18-21$ & $89-105$ & $175-216$ \\
\hline 2006 & $76-93$ & 8 & $24-27$ & 104 & $212-232$ \\
\hline 2007 & $85-98$ & 14 & $26-27$ & $103-114$ & $228-253$ \\
\hline 2008 & $93-101$ & $25-26$ & $22-24$ & $80-111$ & $220-262$ \\
\hline 2009 & $92-112$ & $20-26$ & $16-23$ & $93-137$ & $227-298$ \\
\hline 2010 & $130-155$ & $24-26$ & $20-24$ & $78-116$ & $252-321$ \\
\hline 2011 & $127-150$ & $20-27$ & $19-25$ & $100-127$ & $266-329$ \\
\hline 2012 & $117-145$ & $13-19$ & $22-26$ & $145-178$ & $297-368$ \\
\hline 2013 & $211-271$ & $18-23$ & 20 & $74-83$ & $323-397$ \\
\hline
\end{tabular}

Table 4. Dynamics of the Kisalföld's (Hungary and Austria) spring Great Bustard population between 1990-2011 (Raab et al. 2010 and updated)

4. táblázat A Kisalföld (Magyarország és Ausztria) tavaszi túzokállományának dinamikája 1990-2011 (Raab et al. 2010 és aktualizálva)

late that this population size is limited by the carrying capacity of this territory.

Around this time, however, we also noticed a gradual resettlement of the Great Bustards in the neighbouring Austrian and Slovakian regions (Raab et al. 2010), and they also appeared south of the Mosonszolnok region of the LAJTA Projects, as well as in the Lébény range (Faragó \& Spakovszky 2012) (Table 4, Maps 2 -3).

Some of the data showed drastic changes from year to year in certain regions which can be explained by the leks which were originally undisturbed areas and as such were frequently visited by the birds. The most significant accomplishment of this conservation effort was that, when compared to the initial population size of the Project in the early days, the bustard population later quadrupled and numbered over 400 individuals in the region!

\section{Population dynamics of huntable coexisting species}

Based on the 'wise use' concept (Robertson 1991), there can be no doubt that any improvement to the habitat structures and reduction in disturbance not only positively impact on the Great Bustard population but also positively influence other coexistent protected bird and huntable game populations.

Along with a slight increase in population numbers, we also observed a concentration of Roe Deer in the area, especially between September and April. Exact numbers can be determined from the changes of hunting bag sizes (Figure 3). Hunting bag of the Roe Deer reflects the population dynamics of this species. The Roe Deer population, numbering almost 300 individuals, is significantly underutilized in the Project's region, 


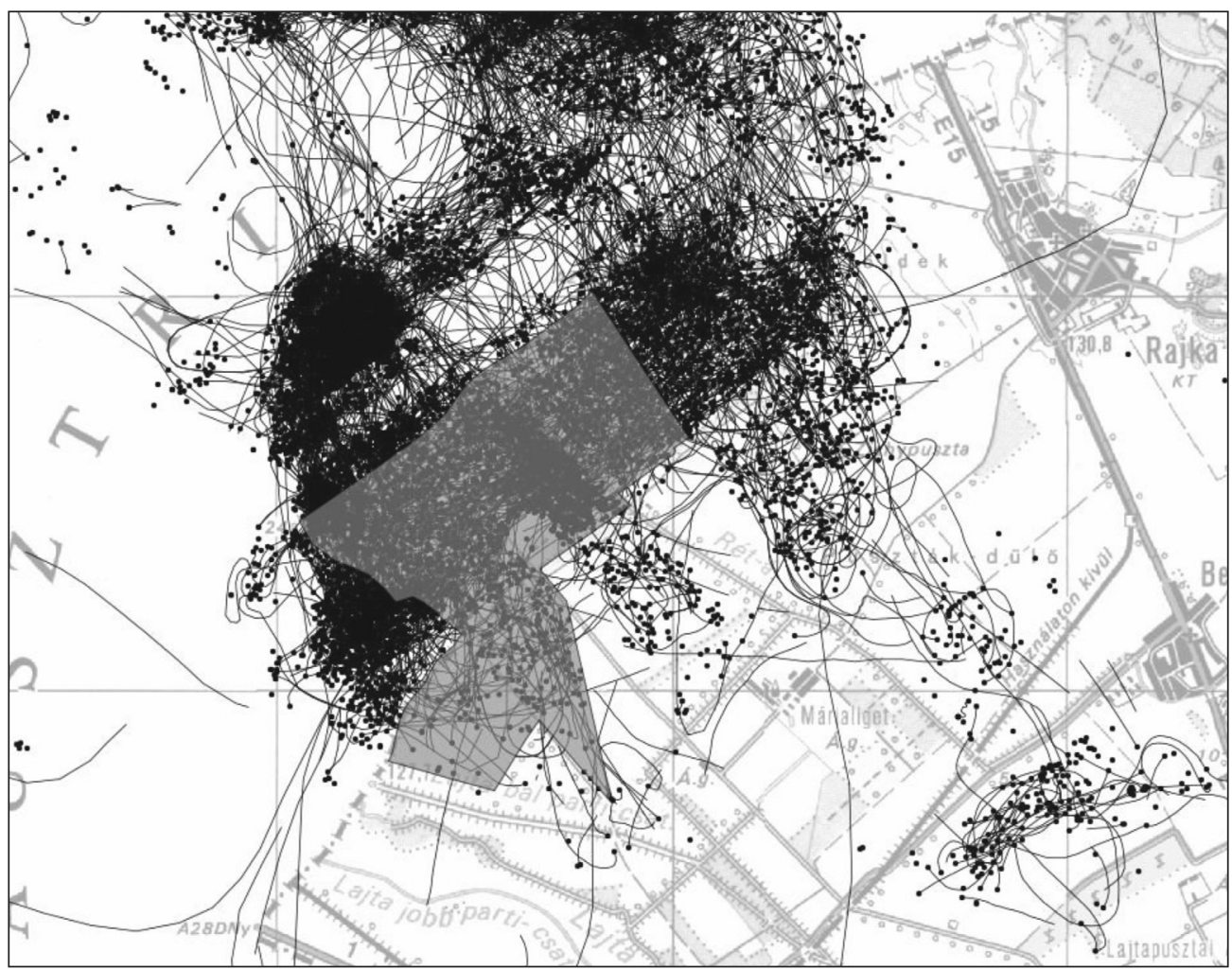

Map 2. Distribution and movement of the Great Bustard population in the MOSON Project region 2. térkép A túzok elterjedése és mozgása a MOSON Project térségében

which situation has improved somewhat in the latter years. In spite of this underutilization, the Project has been able to produce trophies every year which had a medal or even sometimes the gold medal awarded. The number of Roe Deers significantly increased by $2.8(\mathrm{SE}=0.8, \mathrm{P}=0.00275)$ animals during the years.

The greatest positive result was seen in the dynamics of the Brown Hare hunting bag. Since the initiation of the Project, the original number of hunting bag of this species (333 individuals) almost doubled after the first years, which resulted in the shooting of an additional 280 animals in 1992 compared to 1991, and 314 animals more in 1993. As a direct consequence of all the habitat development in the area, the hunting bag grew over 1000 animals by 1994 and over 1500 animals by 1995 . Within 5 years, the hunting bag for the Brown Hare has quintupled. In 1997, there was a slight decline in the size of that year's hunting bag as the hunts resulted in the shooting of only 1200 animals, but in 1999, the hunting bag of the Hare again numbered 1200 individuals. As it was already mentioned in case of the Great Bustard population, in 2000 and 2001, the extreme drought event that occurred during the breeding season also had a negative impact on the Brown Hare population. In these years, the hunting bags of 2000 and 2001 had only 800 and 464 individuals, respectively, even though in the 


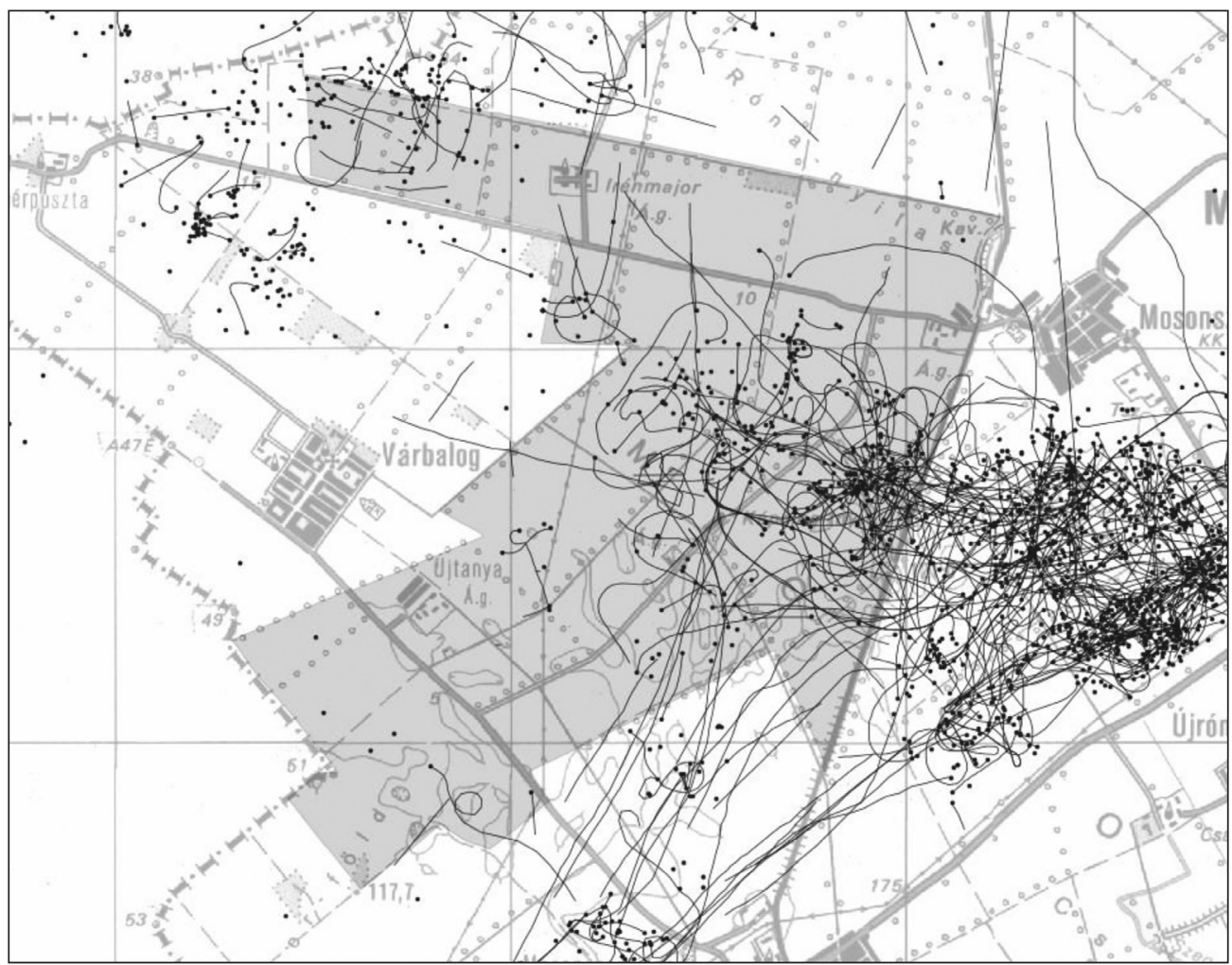

Map 3. Distribution and movement of the Great Bustard population in the LAJTA Project region 3. térkép A túzok elterjedése és mozgása a LAJTA Project térségében

spring, these numbers were expected to be much higher. After a short increasing period, there was a significant decrease in the number of Brown Hares after 1996. The yearly decreasing rate was $54.7(\mathrm{SE}=14.8$, $\mathrm{P}=0.00192$ ) animals.

\section{Discussion}

Our results show that the parameters of Great Bustard-friendly habitats outlined earlier, especially the extensively managed lek territories and surrounding regions (including fallows), have great capacity to attract and support the Great Bustard population. All factors such as the calm, undisturbed surroundings in the mating and nesting season, the diverse habitat structure, the favourable microclimatic conditions and ample food availability, all contribute to the success of such territories. The fallows and the 'bustard fields', which are specifically planted with a diverse crop selection, provide not only the necessary amount of animal food availability, mostly Arthropods, for the chicks, but also provide much needed quality and diversity in their diet. The implemented, almost entirely chemical-free, agricultural activity in the protected habitats ensures that any direct or indirect chemical exposure to pesticides is prevented. Last but not least, with this technique, we can avoid those damages and losses that occur as a result of agricultural practices that utilize mechanized 


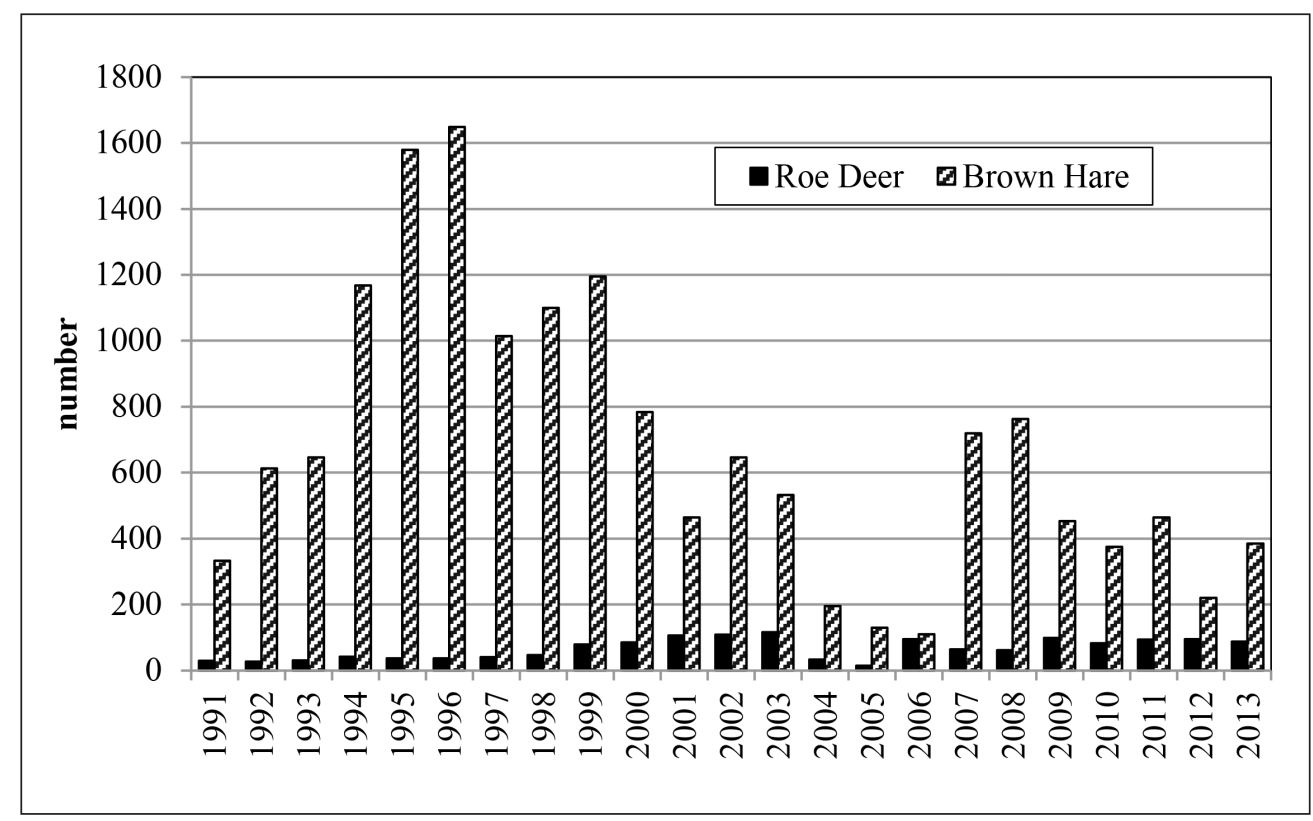

Figure 3. Utilization dynamics of the Brown Hare and Roe Deer in the MOSON Project between 1991-2013 3. ábra A mezei nyúl és az őz hasznosítás-dinamikája a MOSON Projectben 1991-2013

methods (such as mowing or cutting) and which pose the greatest danger to the Bustards. These techniques resemble conditions that are similar to those of the $19-20^{\text {th }}$ century when the Hungarian agriculture was extensive and which period also coincided with the 'golden age' of small game populations (Faragó 1997). It has been conclusively shown by earlier Spanish (Alonso \& Alonso 1990) and several Hungarian habitat preference studies (Faragó \& Kalmár 2006, 2007, Kalmár \& Faragó 2008, Faragó \& Spakovszky 2012) that positive territorial characteristics and supportive habitat development have great positive influence on local communities (Table 5).

The significance of fallow lands (shortand longterm fallows) / uncultivated agricultural lands, as well the presence of stubble fields, is supported by several Spanish studies (Alonso \& Alonso 1990, Lane et al. 2001, López-Jamar et al. 2011). This signi- ficance is especially important in those regions where infrastructure development has taken over or where utilization of the specific land areas changes. In addition to these habitat types, preferential selection for alfalfa-type habitats has been demonstrated both by Alonso and Alonso (1990) and by our own observations in different study areas (Faragó \& Kalmár 2006, 2007, Kalmár \& Faragó 2008). In general, it can be concluded that there is a spatial and temporal variability in the selection of preferred habitat types (Martín et al. 2012). The key significance of crop lands is that they provide nesting sites for the birds (see Magaña et al. 2010). However, these lands are also important habitats for Great Bustards in other times of the year when these crop fields enter the stubble or fallow land phase.

Great Bustards clearly avoid urban or developed rural areas and high traffic roads (usually the artefacts of human activity), or 


\begin{tabular}{|l|c|c|c|c|c|c|c|c|c|c|c|c|}
\hline \multirow{3}{*}{ Habitat } & \multicolumn{4}{|c|}{$2005 / 2006$} & \multicolumn{4}{c|}{$2006 / 2007$} & \multicolumn{4}{c|}{$2007 / 2008$} \\
\cline { 2 - 14 } & Spring & Summer & Fall & Winter & Spring & Summer & Fall & Winter & Spring & Summer & Fall & Winter \\
\hline Fallow & $\mathbf{0 . 8 4}$ & $\mathbf{0 . 8 3}$ & -1.00 & -0.98 & $\mathbf{0 . 7 7}$ & 0.42 & -1.00 & -1.00 & $\mathbf{0 . 7 8}$ & $\mathbf{0 . 7 7}$ & -0.61 & -0.65 \\
\hline Rape & -0.76 & 0.00 & $\mathbf{0 . 8 1}$ & $\mathbf{0 . 8 6}$ & $\mathbf{0 . 5 2}$ & 0.00 & $\mathbf{0 . 7 4}$ & $\mathbf{0 . 7 7}$ & -0.13 & 0.00 & $\mathbf{0 . 7 7}$ & $\mathbf{0 . 7 7}$ \\
\hline $\begin{array}{l}\text { Volunteer } \\
\text { plants }\end{array}$ & -1.00 & -1.00 & $\mathbf{0 . 8 6}$ & -1.00 & 0.00 & -0.12 & $\mathbf{1 . 0 0}$ & 0.00 & $\mathbf{0 . 8 6}$ & -0.46 & -1.00 & -0.90 \\
\hline Winter wheat & -0.38 & 0.00 & -1.00 & -0.71 & - & - & - & - & -0.60 & 0.00 & -1.00 & -0.98 \\
\hline Stubble & -1.00 & -0.37 & -1.00 & -1.00 & -1.00 & 0.26 & -1.00 & 0.11 & 0.00 & -0.18 & 0.00 & 0.00 \\
\hline Plough-land & -1.00 & -1.00 & -1.00 & -1.00 & -0.74 & -0.96 & -0.55 & -0.77 & -0.64 & -0.56 & -0.38 & -0.73 \\
\hline Grassland & - & - & - & - & $\mathbf{0 . 6 2}$ & 0.22 & -1.00 & -1.00 & - & - & - & - \\
\hline Alfalfa & - & - & - & - & -0.15 & 0.08 & -1.00 & -1.00 & -0.67 & -0.75 & -1.00 & 0.09 \\
\hline
\end{tabular}

Table 5. Preferred habitats (Ivlev-index) of the Great Bustard in the Mosoni-plain (2005-2008) (based on Faragó \& Kalmár 2006, 2007, Kalmár \& Faragó 2008)

5. táblázat A túzok élőhely preferenciái (Ivlev-index) a Mosoni-síkon (2005-2008) (Faragó \& Kalmár 2006, 2007, Kalmár \& Faragó 2008 alapján)

habitats where they have no clear horizontal view of their surroundings (Alonso \& Alonso 1990, Lane et al. 2001, Osborne et al. 2001). All Spanish authors take note of the Great Bustards' habitat fidelity which is not only limited to their leks but also to their nesting sites and wintering territories (Alonso \& Alonso 1990, Alonso et al. 2000, Lane et al. 2001, Osborne et al. 2001). These observations are also supported by our study and the successful rehabilitation of the MOSON Project region and its Great Bustard population.

This habitat fidelity is especially important in the West region of the Carpathian basin where winter migration of Great Bustards occurs only in extreme weather conditions (Faragó 1990b). The Spanish Great Bustard populations, however, show partial, short/medium distance migration in their area (Alonso et al. 1995, Alonso et al. 2000, Alonso et al. 2001). As a result of this, we can say that in the West-Pannonian region, the conservation of lek and surrounding habitats are of greatest importance to the local Great Bustard population.
Habitat management also positively influences other bird communities, as habitat structures like fallow lands, depending on duration of the resting phase, support diverse bird communities and increase population sizes, as this has been demonstrated by Kovács et al. (2009) on the Hevesi-Plain (NE-Hungary). We also see similar patterns in the MOSON Project and its surrounding regions in Austria (Raab et al. 2010). An increase in diversity and size of animal communities inherently attract larger numbers of predators which in general, as well as in case of the Great Bustard population, also intensifies predation pressure on prey species in the region. Often, like it is in the case of eagles, they can have such drastic impact on some other species that habitat selection and dispersion is greatly limited, which may even lead to relocation from that region (Spakovszky 2009). This predator pressure partly explains the drastic reduction of the Brown Hare population. However, in this case, another significant influencing factor was the appearance of the European Brown Hare Syndrome (EBHS) virus in the begin- 
ning of 2000's, which, due to the high population density in the region, became the most important population-limiting factor.

In many Western European countries most of the research work focuses on the limitations or lack of continuous coverage of agri-environmental protection programs (Llusia \& Onate 2005, Kleijn et al. 2006), and similar conclusions were drawn in the Dévaványa region and the Bihari-plain (Nagy et al. 2008) or in the Kiskunság by Németh et al. (2009). We, on the other hand, can only attest to the success of the Mosoni-plain conservation program. The reason for that is that while others point to this as negative criticism, on the Mosoni-plain, due to the size of the Lajta-Hanság Co. territory, we were able to include in the program such key land areas (lek territory, nesting sites, wintering habitats). This had significant and relevant effect on the recovery and stability of the Great Bustard population and eventually led to the expansion of their local population. In the MOSON Project, such measures as delaying the commencement of reaping or stem-crushing further reduced those losses which would have normally occurred from these technologies.

Another important achievement of this Project was that while the Mosoni-plain was not listed as an important Hungarian bird habitat up until 1989 (Waliczky 1992), by the second half of the 1990's, the Mo- soni-plain was given IBA (Important Bird Area) status based on the new criteria of the National and European significant habitats list. The Mosoni-plain was listed with the code number of HU-001, a region of 4310 hectares included and protected species were the Otis tarda and the Perdix perdix (Nagy 1998, Nagy 2000). Based on all these, in 2004, the territory was placed under Natura 2000 (European Union Nature Conservation Network) protection. The MOSON Project served as model for the creation of the Hungarian Great Bustard Conservation Program (Faragó et al. 2013) and it also provided the basis for the Bustard LIFE Project between 2005-2008 (Faragó \& Kalmár 2006, 2007, Kalmár \& Faragó 2008, Faragó \& Kalmár 2011).

\section{Acknowledgement}

We shall express our greatest gratitude to all those who have supported the above project during its almost quarter-century span. We would like to thank the management of the Lajta-Hanság Co.: Frigyes Nagy, Jenő Nagy and József Preiner CEOs.; Ferenc Giczi Director of Hunting of Area; Directors of the Fertö-Hanság National Park: László Kárpáti and Gábor Reischl; as well as, Hans Wurm, Hans-Peter Kollar and Gerald Dick from Austria. 


\section{References}

Alonso, J. C. \& Alonso, J. A. (eds.) 1990. Parametros demograficos, seleccion de habitat y distribution de la avutarda (Otis tarda) en tres regiones Españolas [Demographic parameters, habitat selection and distribution of Great Bustards (Otis tarda) in three Spanish regions]. - ICONA F.E.P.M.A. Madrid, Spain

Alonso, J. C., Alonso, J. A., Martín, E. \& Morales, M. 1995. Range and patterns of Great Bustard movements at Villafafíla, NW Spain. - Ardeola 42(1): 69-76.

Alonso, J. C., Morales, M. B. \& Alonso, J. A. 2000. Partial migration, and lek and nesting area fidelity in female Great Bustards. - The Condor 102: 127-136.

Alonso, J. C., Martín, C. A., Alonso, J. A., Morales, M. B. \& Lane, S. J. 2001. Seasonal movement of male Great Bustards in Central Spain. - Journal of Field Ornithology 72(4): 504-508.

Faragó, S. 1978. A Hanság és környékének túzokállománya [Great Bustard population of Hanság]. Nimród Fórum 1978. június: 1-5. (in Hungarian)

Faragó, S. 1979. A környezeti tényezők hatása a Hanság túzokállományára [Impact of environmental factors on Great Bustard in Hanság]. - Állattani Közlemények 66: 65-73. (in Hungarian with English Summary)

Faragó, S. 1981. Összehasonlító mikroklíma-vizsgálatok a túzok (Otis t. tarda L.) hansági fészkelöhelyén [Comparative microclimatic examinations of Great Bustards (Otis t. tarda L.) in their main nesting biotopes in Hanság]. - Nimród Fórum 1981. március, Vadbiológiai Kutatás 27: 2532. (in Hungarian)

Faragó, S. 1982. A Hanság környéki túzokállomány, 5 éves magyar-osztrák szinkronfelvételek alapján [The Great Bustard population of Hanság region, after 5 years Hungarian-Austrian synchronous survey]. - Állattani Közlemények 69: 75-84. (in Hungarian with English Summary)

Faragó, S. 1986a Izolálódott túzokpopulációk védelmének kérdései a Kárpát-medence nyugati túzoknépességeinek példáján [Problems of protection of isolated Bustard populations]. - Állattani Közlemények 72: 53-60. (in Hungarian with English Summary)

Faragó, S. 1986b Az európai túzok (Otis tarda Linné, 1758) növényi és állati eredetü táplálékának fajspektruma az area területén [A variety spectrum of the originally vegetable and animal food for European Bustard (Otis tarda Linné, 1758) in the area]. - Erdészeti és Faipari Tudományos Közlemények 1985(1-2): 121-130. (in Hungarian with German Summary)
Faragó, S. 1988. A túzok-félék (Otididae) előfordulása és elterjedése az Alpokalján [The presence and spreading of Otididae in the Praenoricum]. - Praenorica Folio Historico Naturalia 2: 149-158.

Faragó, S. 1989. A mezőgazdaság hatása a túzok (Otis tarda L.) állományra Magyarországon [Effect of agriculture on Great Bustard (Otis tarda L.) population in Hungary]. - Nimród Fórum 1989. október: 12-30. (in Hungarian)

Faragó, S. 1990a A túzok Magyarországon [The Great Bustard in Hungary]. - Venatus Budapest, pp. 78 (in Hungarian)

Faragó, S. 1990b A kemény telek hatása Magyarország túzok (Otis tarda L.) állományára [The effect of heavy winters on Bustard (Otis tarda L.) populations in Hungary]. - Állattani Közlemények 76: 51-62. (in Hungarian with English Summary)

Faragó, S. 1993. Development of Great Bustard populations in Hungary in the period 1981-1990. - Folia Zoologica 42(3): 221-236.

Faragó, S. 1996a Lage des Grosstrappenbestandes in Ungarn und Ursachen für den Bestandsrückgang [Status of Great Bustard population in Hungary and the causes of its decrease]. - Naturschutz und Landschaftspflege in Brandenburg 5(1-2): 12-17. (in German with English Summary)

Faragó, S. 1996b Trappenschutz in Ungarn - Theorie und Praxis [Great Bustard conservation in Hungary - Theory and practice]. - Naturschutz und Landschaftspflege in Brandenburg 5 (1-2): 9598. (in German with English Summary)

Faragó, S. 1997. Changes in small game habitat structure in Hungary in the last 100 years. - Magyar Apróvad Közlemények 1: 89-106.

Faragó, S. 2006. One-hundred-year trend of the Great Bustard (Otis tarda) population in the Kisalföld Region. - Aquila 112: 153-162.

Faragó, S., Bodnár, M., Borbáth, P., Boros, E., Fatér, I., Kapocsi, I., Kurpé, I., Motkó, B., Mödlinger, P. (†), Széll, A., Tóth, L., Ványi, R. \& Végvári, Zs. 2013. Program a túzok (Otis tarda) védelmére Magyarországon [The Hungarian Great Bustard (Otis tarda) Conservation Program]. - Magyar Apróvad Közlemények 11: 59-106. (in Hungarian with English Summary)

Faragó, S., Giczi, F. \& Wurm, H. 2001. Management for the Great Bustard (Otis tarda) in Western Hungary. - Game and Wildlife Science 18 (2): 171181.

Faragó, S. \& Kalmár, S. 2006. A túzok védelme Magyarországon. LIFE Nature Project 2005. évi monitoring jelentése [Conservation of Great Bustard in Hungary. Monitoring report of LIFE Nature 
Project in 2005]. - Magyar Apróvad Közlemények Suppl., pp. 142 (in Hungarian)

Faragó, S. \& Kalmár, S. 2007. A túzok védelme Magyarországon. LIFE Nature Project 2006. évi monitoring jelentése [Conservation of Great Bustard in Hungary. Monitoring report of LIFE Nature Project in 2006]. - Magyar Apróvad Közlemények Suppl., pp. 184 (in Hungarian)

Faragó, S. \& Kalmár, S. F. 2011. A túzok (Otis tarda) állományváltozása Magyarországon - a LIFE túzokvédelmi program monitoringeredményei alapján [Population dynamics of Great Bustard (Otis tarda) in Hungary based on the results of the monitoring of the LIFE Great Bustard conservation programme]. - Aquila 118: 55-80. (in Hungarian with English Summary)

Faragó, S. \& Spakovszky, P. 2012. A túzok a LAJTA Projectben [The Great Bustard in the LAJTA Project]. - In: Faragó, S. (szerk.) A LAJTA Project. Egy tartamos mezei vad és ökoszisztéma vizsgálat 20 éve [The LAJTA Project. 20 years of a long term monitoring of small game populations and their agri-ecosystems]. - Nyugat-magyarországi Egyetem Kiadó, pp. 364-403. (in Hungarian)

Faragó, S., Triebl, R. \& Chobot, J. 1987. Die Beziehungen des Grosstrappenbestandes im Karpaten-Becken [Situations of Great Bustard populations in the Carpathian Basin]. - In: Faragó, S. (ed.) Proceedings of the CIC Great Bustard Symposium in Budapest, on June 2. pp. 77-90. (in German with English and French Summary)

Kalmár, S. \& Faragó, S. 2008. A túzok védelme Magyarországon. LIFE Nature Project 2007-2008. évi monitoring jelentése [Conservation of Great Bustard in Hungary. Monitoring report of LIFE Nature Project in 2007-2008]. - Magyar Apróvad Közlemények Suppl., pp. 282 (in Hungarian)

Klejn, D., Baquero, R. A., Clough, Y., Diaz, M., De Esteban, J., Fernández, F., Gabriel, D., Herzog, F., Holzschuh, A., Jöhl, R., Knop, E., Kruess, A., Marshall, E. J. P., Steffan- Dewenter, I., Tscharntke, T., Verhulst, J., West, T. M. \& Yela, J. L. 2006. Mixed biodiversity benefits of agri-environment schemes in five European countries. - Ecology Letter 9(3): 243-254.

Kovács, A., Báldi, A., Batáry, P. \& Tóth, L. 2009. Az ugarok jelentősége a madárvédelemben a Hevesi-sík Érzékeny Természeti Területen [The role of set-aside in the conservation of birds on the Heves Environmentally Sensitive Area]. - Természetvédelmi Közlemények 15: 193-203. (in Hungarian with English Summary)

Lane, S. J., Alonso, J. C. \& Martín, C. A. 2001. Habitat preferences of Great Bustard Otis tarda flocks in the arable steppes of central Spain: are potential- ly suitable areas unoccupied? - Journal of Applied Ecology 38: 193-203.

Llusia, D. \& Onate, J. J. 2005. Are the conservation requirements of pseudo-steppe birds adequately covered by Spanish agri-environmental schemes? A ex-ante assessment. - Ardeola 52: 31-42.

López-Jamar, J. L., Casas, F., Díaz, M. \& Morales, M. B. 2011. Local differences in habitat selection by Great Bustard Otis tarda in changing agricultural landscapes: implications for farmland bird conservation. - Bird Conservation International 21(3): 328-341.

Martín, B., Alonso, J. C., Martín, C. A., Palacín, C., Magaña, M. \& Alonso, J. 2012. Influence of spatial heterogenity and temporal variability in habitat selection. A case study on a Great Bustard metapopulation. - Ecological Modelling 228: 39-48.

Magaña, M., Alonso, J. C., Martín, C. A., Bautista, L. M. \& Martín, B. 2010. Nest-site selection by Great Bustards Otis tarda suggests a trade-off between concealment and visibility. - Ibis 152(1): 77-89.

Nagy, Sz. 1998. Fontos madárélőhelyek Magyarországon [Important bird areas in Hungary]. - Magyar Madártani és Természetvédelmi Egyesület, Budapest, pp. 138 (in Hungarian)

Nagy, Sz. 2000. Hungary. - In: Heath, M. \& Evans, M. I. (eds.) Important Bird Areas in Europe. Priority sites for conservation. Vol. 2.: Southern Europe, Cambridge, UK, BirdLife International (BirdLife Conservation Series No. 8.). pp. 335-355.

Nagy, Sz., Széll, A. \& Motkó, B. 2008. Hatásosak-e a túzok (Otis tarda) védelmét szolgáló magyar agrár-környezetvédelmi intézkedések? [Are the Hungarian agri-environmental measures effective for the conservation of Great Bustard (Otis tarda)?] - Aquila 114-115: 47-55. (in Hungarian with English Summary)

Németh, Á., Lóránt, M. \& Vadász, Cs. 2009. Mennyire tekinthetők hatékonynak az Agrár-Környezetgazdálkodási Program túzokvédelmi célprogramjaiban szereplö elöírások? [How effective are the management regulations of the Great Bustard Protection Agro-Environmental Program?] - Természetvédelmi Közlemények 15: 226-234. (in Hungarian with English Summary)

Osborne, P. E., Alonso, J. C. \& Bryant, R. G. 2001. Modelling landscape-scale habitat use using GIS and remote sensing: a case study with Great Bustards. - Journal of Applied Ecology 38: 458-471.

Palacín, C., Alonso, J. C., Martín, C. A. \& Alonso, J. A. 2012. The importance of traditional farmland areas for steppe birds a case study of migrant female Great Bustards Otis tarda in Spain. - Ibis 154 (1): 85-95. 
Raab, R., Kollar, H-P., Winkler, H., Faragó, S., Spakovszky, P., Chavko, J., Maderic, B., Skorpiková, V., Patak, E., Wurm, H., Julius, E., Raab, S. \& Schütz, C. 2010. Die Bestandsentwicklung der westpannonischen Population der Grosstrappe, Otis tarda Linnaeus 1758, von 1900 bis zum Winter 2008/2009. [Development of the West Pannonian population of the Great Bustard, Otis tarda Linnaeus 1758, from 1900 to the winter 2008/2009]. - Egretta 51: 74-99. (in German with English Summary)

Raab, R., Kovacs, F. J., Julius, E., Raab, S., Schütz, C., Spakovszky, P. \& Timar, J. 2010. Die Grosstrappe in Mitteleuropas. Erfolgreicher Schutz der westpannonischen Population [The Great Bustard in Central Europe. Successful conservation of the West-Pannonian population]. - Austrian Power Grid AG, Wien, pp. 304 (in German)

Reiczigel, J., Harnos, A. \& Solymosi, N. 2007. Biostatisztika nem statisztikusoknak [Biostatistic for non statisticians]. - Pars Kft, Nagykovácsi, pp. 465 (in Hungarian)
Robertson, P. 1991. Wise use and conservation. - Gibier Faune Sauvage 8: 379-388.

Spakovszky, P. 2009. Túzokok (Otis tarda) változó területhasználata egy új parlagisas-revírben (Aquila heliaca) a Mosoni-síkon [Altering habitat use of Great Bustards (Otis tarda) in a new Imperial Eagle (Aquila heliaca) territory in the Mosoni-sík, Northwest-Hungary]. - Természetvédelmi Közlemények 15: 528-533. (in Hungarian with English Summary)

Spakovszky, P., Pellinger, A. \& Burda, B. 2011. A mosoni túzok (Otis tarda) állomány hosszú távú fenntartásának természetvédelmi problémái [Nature conservation problems of sustaining the population of the Great Bustard (Otis tarda) on the Moson Plain on the long term]. - Ornis Hungarica 19: 133-140. (in Hungarian with English Summary)

Waliczky, Z. 1992. Európai jelentőségủ madárélőhelyek Magyarországon [Bird areas in Hungary with European importance]. - Magyar Madártani és Természetvédelmi Egyesület, Budapest, p. 71. (in Hungarian)

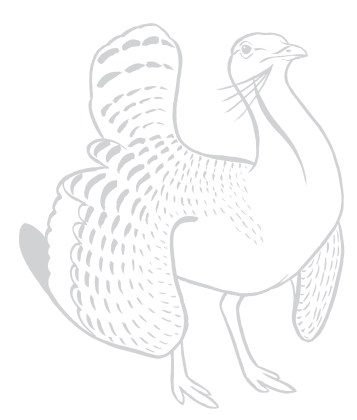

